\title{
Adult Interest On Following English Course at BEC Kampung Inggris Pare Kediri
}

\author{
Wiwin Yulianingsiha, Supriyono, Ach. Rasyad, Umi Dayati \\ Non Formal of Education Department, Universitas Negeri Malang \\ Jln. Semarang No. 5, Sumbersari, Lowokwaru, Malang City, East Java, Indonesia \\ Corresponding e-mail: awiwin.yulianingsih@yahoo.co.id
}

\begin{abstract}
The purpose of this study is 1). To describe the learning programs in BEC, 2). To describe and analyze the meaning of adult interest in attending English courses at BEC. This research was conducted with qualitative approach with phenomenology design of data collection under three techniques, namely: 1). In-depth interview, 2). Observation, 3). Documentation. The results of the study that is 1). Communication as an action or one-way communication puts instruction as an action giver, active instructor to passive course participants. 2). Communication as a two-way interaction or communication, the instructor acts as the actor or the recipient of the action, 3). Communication as a transaction or communication. While the interest of adult learners in English courses are 1). BEC is the pioneer institution of the course, the oldest course institution, very famous due to its successful alumni, awarded by the ministry of education for its dedication in English education. 2). BEC values brotherhood and religion 3). BEC makes rules to every participant to speak English in the BEC area and intensive meeting arena and thus put pride amongst the participants 4). The cheap cost of the courses that can be reached by every people and the time or duration given for learning activities is quite proportional. 5). In BEC they can seek new experiences like teaching practices, English communication with other course participants, new friends, new family, including looking for spouse.
\end{abstract}

Keywords: Interest, adults learning

\section{INTRODUCTION}

The need for English proficiency can be fulfilled through the educational process. The educational process is a conscious and well-planned effort to create an atmosphere and learning process, so that learners can be actively developing their own potential skills, to possess intelligence and skills needed for themselves and society [2].

Therefore, Education is viewed as an ongoing process guided by the objective of improving the quality of life, especially adults, students, college students, workers, practitioners and educators must have English language skills to enhance their role in life.

Adult education has different approaches, scopes, goals and strategies compared to education for children. Adult education focuses on long-life learning to learn skills that can be used in self-direction. When carrying out their education process, adults prefer to study in flexible conditions, not like rote, prefer to solve problems and practical matters. One of the institutions dealing with the problem to fulfill the learning needs is the course institution [1]. Course institution is a nonformal education institution that aims to provide a good science of knowledge and skills so it can be used in their community life. It is in line with the notion of the course in the decision of the general director of non-formal education, youth and sports. No. KEP-105 / E / L / 1990.

Their interest is the same as their needs. Participants' involvement is the requirement of English ability that can be fulfilled by the process of non-formal education through their participation of learning English courses. This is in accordance with the opinion of $\mathrm{J}$. Rogers[3]. that the types of adults are divided into five levels below, including the need to learn English.

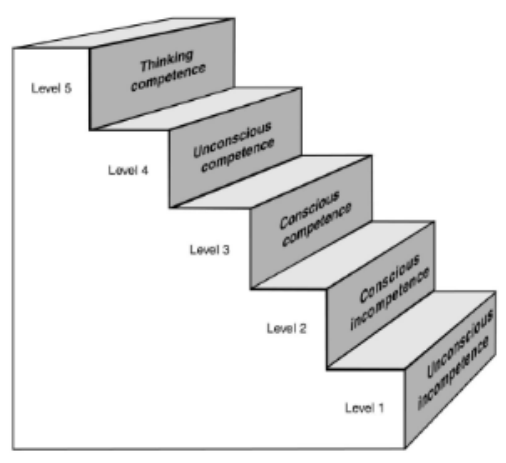

Figure. 1. The Ladder of competence

In his stages, Jenny in the book Adult Learners: Includes 1. unconscious incompetence (Adults do not realize and doesn't have proper skills), conscious incompetence (They realize that they haven't proper 
skills), conscious competence (They realize about their skills and potentials), 4 Unconscious competence (competence but not aware of it), 5. thinking competence (having the competence of thinking, so that the need of learning and developing arises to what else is needed). Of the five stages of adults thinking will cause a person's learning needs. It can be argued that the adult education's progressiveness reverses the focus of learning centered from teacher centered, to student centered, and from academic idealism to pragmatism or real educational needs in society.

The public interest phenomenon that chose BEC as one of the best course institutions. The attractiveness of the BEC institute includes learning with an interesting learning system and learning components, which all encompassed in an organizing process as to produce competent graduates and qualified learners in the field of English. In this study, the focus is on one BEC institution that has the characteristics of learning with strict rules for course participants, as the main informant, which will see, examine, and observe in depth.

\section{METHOD}

This study examines and reveals the focus of research relating to English language learning programs on adult participant at the BEC course in the Kampung Inggris Pare Kediri. The qualitative approach is an appropriate decision to describe the English language learning program at the BEC. Qualitative research is a process of inquiry to understand and deepen a phenomenon related to social and personal problems. Defines qualitative research as a process of research to understand human or social problems by creating comprehensive and complex images presented in the form of words, reporting detailed views obtained from informed sources, and conducted in a natural setting[4].

Sources of data collected in this study are primary data sourced from learners, tutors, and course organizers. Researchers seek to collect data and review processes, events, or activities undertaken by informants and other sources. In line with the role of the researcher, in qualitative research the data collected in the form of written or oral words and behavior of people who can be observed by researchers and this time, methods used in data collection include interviews, observation, and documentation. Checking the validity of the data in accordance with the characteristics of qualitative research, thus there are special standards that must be met in qualitative research. According there are 4 main types of standards or criteria to ensure the trustworthiness or the truth of qualitative research results including: Credibility (In the degree of credibility, the researcher uses two examination techniques named
Triangulation and Member check), Transferability, Dependability and Confirmability.

\section{RESULT AND DISCUSSION}

The result of this research is that the learning program in $\mathrm{BEC}$ is managed through intensive management of learning by dividing it into three learning programs, namely BTC (Basic Training Course), CTC (Candidate Training Class), TC (Training Class). There are three communication patterns in the interaction process, instructor to the course' participants, that is 1). Communication as an action or one-way communication puts instruction as an action giver, active instructor to passive course participants. 2). Communication as a two-way interaction or communication, the instructor acts as the actor or the recipient of the action, 3). Communication as a transaction/communication are not only used between instructors and course participants but also between each of course participants. BEC's teaching methods include question and answer, discussion or debate, group work (performance), assignments and games.

Carl Rogers stated that humans have a natural instinct and desire to become a better human being. Humanistic approach in education emphasizes the positive development of man, namely concentration on human potential to search and find capabilities they have, including interpersonal skills, social and personal development. Carl Rogers in his book titled The Freedom to Learn mention a number of basic humanistic principle, including:

1. Humans have ability to learn naturally.

2. Learn will effective when the subject matter was relevant to what is felt by students (learners).

3. Learning that involves a change in the students / learners tend to be seen as threatening and rejection.

4. Learning will meaningful if learning involves students / learners.

5. The process of teaching and learning activities will be smooth if students/ learners involved in the teaching process itself.

6. Self-confidence, independence and creativity are more easily achieved if the student is accustomed to introspection by way of criticizing himself.

Dewey's basic principals in The Adult Learner 1). Educators expose participants to new possibilities for their own self-fulfillment. 2). Educators help each student clarify their own aspirations for behavioral improvement. 3). Educators help each student diagnose the gap between aspiration and the current level of performance. 4). Educators help students identify the problem of life they've experienced because of the gap in their personal condition. 5). Educators provide a comfortable physical condition (for sitting, temperature, ventilation, lighting, decoration) and conducive for 
interaction activity (preferably, no one sitting behind others). 6) The educator accepts every student as a decent person and respects his or her feelings and ideas. 7). Educators seek to build trusting and helping relationships among students by encouraging cooperative activities and refraining from encouraging competitiveness and judgmental mentality. 9). Educators confront their own feelings and contribute resources as a co-learner in the spirit of mutual need. 9. Educators involve students' goals in the process of formulating experiences of learning objectives against the needs of students, institutions, teachers, subject matter, and society are also taken into account.10). Educators share their thoughts from around the available options in designing learning experiences and selecting the materials and methods and engage students in deciding between these options together. 11). Educators help students to organize themselves (project groups, Teaching Teams of learning, self-study, etc.) to share responsibilities in the process of mutual need. 12). Educators help learners leverage their own experience as learning resources through the use of techniques such as discussion, role playing, case method, and so on. [7].

Mean while the adult learner interests in English courses are 1). BEC as the pioneer institution of the course, the oldest course institution, very famous for its successful alumni, even was awarded by the ministry of education. 2). BEC values brotherhood and religion 3). BEC makes rules for participants to use English as their daily language in the BEC area and intensive meeting arena, this condition makes the course participants pride for what they deserve 4). The cost of cheap courses that can be reached by every people and the time/duration given for learning activities is quite proportional 5). Seek new experiences like, practice on teaching, English communication with other course participants, get new friends, new family including looking for spouse/mate.

The appeal of English language courses for adults in England Pare village that shows the needs of adult community learning related to improving the competence to find work, preparation for entering college level bachelorand magister or doctor, preparation and competition overseas scholarships included spare time after graduating from high school or equivalent and pass achelorand magister or doctor ,or equivalent. The need to learn the English language in Pare included as part of the implementation of adult learning in terms of answering the needs of a more realistic, one needs to learn English to conditions or circumstances surrounding. So there is a common thread among adults learn learning needs. This is in accordance with the opinion by [7] That the types of adults there are five levels below, including the need to learn English. In stages Jenny said in the book Adult Learners: includes 1. Unconscious incompetence (adults does not realize and do not have the ability), 2. Conscious incompetence (realized and do not have the ability), 3. Conscious competence (awareness of his ability), 4. Unconscious competence (competence but did not realize), 5 . Thinking competence (competence think), so it appears the need to learn what else is needed. From the five stages of thinking adult would cause a person's learning needs. It can be said that adult learning was flipped focus learning teacher centered to student centered, from the academic to the idealistic pragmatism or real educational needs in the community. Because the needs of each individual learner are a perceived need.[5].

In Learning communities, certain views are learned and shared. These views lead learners to be related to a particular community and than commit themselves to it. In learning societes, by contras, each learner is respectful of ther learners self-determination around what they learn. This is not to say that the learning society does not agree on any views while the learning community does. The point is that the agreement does not serve as the goal of development. The agreement in the learning society, if any is to provide room for as much pluralism as possible[6].

While needs and requirement in Romania adult education and training system using modern methods. A moderd and efficient adult training system bring undoubtedly and added value on a human resourse quality a professional. Staff body in institutions and companies, able toraise the performance level and needs another team bulding, benchmarketing coaching and brainstroming[8].

This is in line with the benefits of learning English since English is a unifying language between the nation and language which became the number one language in the World recently. Therefore English is very important and useful for everyday life as quoted from: a). English is able to socialize with the wider community, b). English is used in technology sector, c). English for education, d). English for the work, f). English is capable for mastering the world, meaning that the English language possessed by a person can be used to learn and obtain all of the knowledge, including economics, culture, lifestyle and so on.

\section{CONCLUSION}

a. Communication as an action or one-way communication puts instruction as an action giver, active instructor to passive course participants.

b. Communication as a two-way interaction or communication, the instructor acts as the actor or the recipient of the action.

c. Communication as a transaction/communication. While the interest of adult learners in English courses are:

1) $\mathrm{BEC}$ as the pioneer institution of the course, the oldest course institution, very famous for its 
successful alumni, even was awarded by the ministry of education.

2) Very uphold the value of brotherhood and religion.

3) There is an interesting BEC rule in the form of obliging English course participants to communicate using English language in the $\mathrm{BEC}$ area and intensive meeting arena, and this makes it a pride for them.

4) The cheap cost of the courses that can be reached by every people and the time/duration given for learning activities is quite proportional and tiered.

5) Seek new experiences like, teaching practices, using English communication with other course participants, get new friends, new family, including looking for spouse.

\section{ACKNOWLEDGMENT}

The autors would like to thank the rector Universitas Negeri Surabaya, Dean faculty of education and head of department non formal of education who gave me the opportunity to achive Doctoral Study. I Would like to thank the soceity of Kampung Inggris who gave me the time and change to have an Interview section.

\section{REFERENCES}

[1] Sudjana,H. Djuju. Pendidikan Luar Sekolah: Wawasan, Sejarah perkembangan, Filsafat, Teori Pendukung, Asas. (Bandung: Falah Production), 2001.

[2] UUSPN No 20 Tahun 2003. Pustaka Surabaya. Surabaya. 2005.

[3] Rogers, Jenny, (2007) Adults Learning Fifth Edition. Open University.

[4] Creswell Penelitian Kualitatif \& Desain Riset Mmeilih Di antara Lima Pendekatan John W Creswell. 2015

[5] Adult Education and Lifelong Learning $3^{\text {rd }}$ edition Theory and Practice. Peter Jarvis. London And New York Routledge Falmer Taylor \& Francis Group. 2004.

[6] Yahui Sui The Non-instrumental Vision Of The Learning Society. Published Online 5 Februari 2011.Springer Science+Bussniness.B.V.2011.

[7] Rogers, Jenny, (2007) Adults Learning Fifth Edition. Open University.

[8] Michaela Dimitrescu, Luiza Venera, Sarbu, Ynome Lacroix1. Europen Trends For Adult Education In Lifelong Learning Strategi : Modern 2015 Elseveir Procedia-Sosial and behavior Science.1161-1169. 